\title{
Farming Practices of Rice Farmers in Can-Avid and Dolores, Eastern Samar
}

\author{
Rogelio B. Robedizo
}

\author{
Eastern Samar State University, Borongan, Eastern Samar
}

\begin{abstract}
The research aimed to account for the rice technologies practiced by farmers of Canavid and Dolores, Eastern Samar. These two municipalities are considered as the major rice producing towns of Eastern Samar. It sought to determine the degree of adoption of modern and indigenous rice technologies and to identify the problems met by the farmers in using said technologies. A total of 57 farmers served as respondents. Percentage, means, ranks, and ranges were used to analyse the data.

The mean age of the respondents was 54.94 years old with intermediate as the highest educational attainment with 5.43 years of formal schooling. Majority were married with 17.68 average years of farming. The average farm size was 1.26 has.

The respondents prepared their rice field by trampling, use of native seeds and by winnowing basket in cleaning the palay with a weighted mean score of $2.04,2.5$, and 2.23 respectively. Results also revealed that 71.05 percent were unsuccessful and 28.93 percent were successful or highly motivated while majority of the modern rice farmers were considered successful or highly motivated (67\%).

Lack of knowledge and skills about rice farming, farm implements, and limited capital were the problems met by farmers.
\end{abstract}

Keywords: indigenous rice technologies, farming practices

\section{INTRODUCTION}

Improving agricultural productivity has been the world's primary defense against a Malthusian crisis; the idea that food demand from a rising population will confront limits to natural resources and lead to famine (Ferglie 2012). On the other hand, Ricketts and Ricketts (2013) cited that agriculture has changed. For years, agriculture has become a career and a way of life. Today, however, the agricultural industry is now technologyoriented that includes production, agri-science and agri-business.

Rice farming employs practices and improved technologies starting from land preparation to post harvest operation of the crop. The land preparation of rice farming is laborious and time consuming because of labor intensive tools and equipment used. These equipment are mostly for manual post-harvest activities. In Eastern Samar, modern facilities have been largely ignored by farmers due to financial constraint. Rice farming activities include such cultural practices as cleaning the seedbed for raising the seedlings, transplantation, weeding, harvesting, and postharvest practices.

Asinov (2013) stated that increases in agricultural productivity lead also to agricultural growth and can help to alleviate poverty in poor and developing countries, where agriculture often employs the greatest portion of the population. He explained further that as farms become more productive, the wages earned by those who work in agriculture increase. At the same time, food prices decrease and food supplies become 
more stable.

The present trend in rice farming is focused towards the adoption of new technologies developed through specific researches. The International Rice Research Institute (IRRI), Philippine Rice Research Institute (Philrice) Universities and research centers are intensively working to discover new applicable technologies to help rural farmers obtain better income from their farms (Philrice, 2014; IRRI, 2014).

A number of development programs from government and non-government entities have been launched in an attempt to increase the buffer stock of rice. Financial assistance has also been packaged to help farmers procure the necessary production inputs with the purpose of producing higher yield and/or productivity.

According to Strasbourg (2013), transformation of agriculture into a business activity has created a demand for professional management and use of modern technologies in areas such as specialized production, post harvest management, promotion of value added agri-products, chain management, and marketing.

Moreover, research institutions have focused on the development of low cost farming technologies to solve the farmer financial incapability to follow recommended technologies. However, with the centralized implementation of government programs on rice production, acceptance of appropriate technologies which are location specific have always been a felt difficulty owing to varying cultural patterns among different places. It is natural therefore for farmers in a particular place to resist change in their rice farming practices and remain traditional. Despite the introduction of modern technologies, some farmers are still using the indigenous practices for some reasons. It is however possible through extension programs for farmers in a particular place to accept change and follow the recommended technologies in rice farming.

Indigenous rice farming practices by farmers have been passed on from their forefathers. Farmers continue to adopt these indigenous farming practices in their respective farms in spite of the new technologies available because they believe in their beneficial effects. This study focused on the indigenous rice practices by farmers in Canavid and Dolores Eastern Samar. In particular, the study aimed to account for the rice technologies that were practiced by the farmers in these places. It also determined the degree of adoption of both modern and the indigenous rice farm practices, compared the benefits derived by farmers using the indigenous and the modern technologies, and analyzed the problems met by the farmers in adopting the aforesaid practices and/or technologies.

\section{METHODOLOGY}

This study was conducted in selected barangays (villages) of Can-avid and Dolores, Eastern Samar, Philippines being the rice bowl of the province. Purposive sampling was employed in selecting the barangays studied which included: Malogo, Canteros and Carolina in the Municipality of Can-avid; and Barangays Aroganga, Dampigan and Bonghon in the municipality of Dolores, Eastern Samar. The sites of the study were chosen from among the many barangays of Can-avid and Dolores, Eastern Samar because these barangays were rice producing areas, thus it was believed that farmers may have common problems and practices. These barangays are easily reached by different agents of the government for technology transfer and other new innovations, especially in agriculture.

Twenty five percent of the rice farmers in each of the selected barangays were randomly selected. The rice farmers who were selected comprised the population sample.

Data gathering was done using an interview schedule which was written in English and translated into Waray-Waray to facilitate understanding among the target correspondents.

Frequency counts and percentages were used to describe the demographic characteristics and other sample presentation of the data. The 5 point scale measures was 
used to analyze the degree of adoption of the adopters of both technologies e.g., 1 low, 2 average, and 3 for high adopter.

Branching Diagram Analytic Technique (BRANDANT) (Harris, 1979) was used in determining the performance of rice farmers adopting the indigenous practice, modern technologies, and both modern and indigenous rice farming as reflected in Figure 1.

Variables Analysis Interpretation

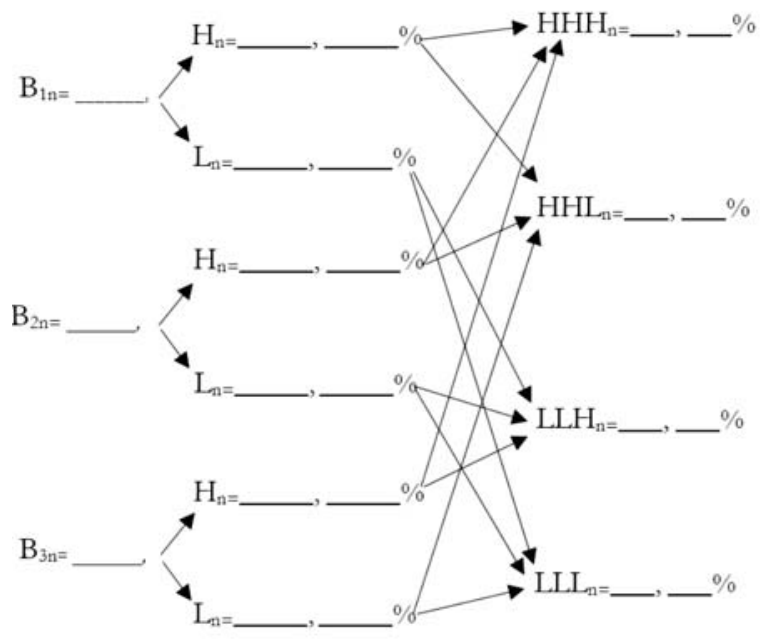

Code:
Very good performance, highly

motivated group, successful

Farm interest group/performing good, near successful

Non-farm motivated performing group fair or near failure

Very poor performance, poorly motivated group, unsuccessful or failure

$\mathrm{H}$ - Average and above average

L-Below Average

Benefits:

$\mathrm{B}_{1}$ - Income in rice farming

$\mathrm{B}_{2}$-Off-farm income

$\mathrm{B}_{3}-$ Social and involvement in community related services

Figure 1. Branching Diagram Analytic Technique (BRANDAT) as a tool in determining the performance of rice farmers in adopting both indigenous practices and modern technologies.

\section{RESULTS AND DISCUSSION}

\section{Characteristics of farmers}

The rice farmers of Can-avid and Dolores, Eastern Samar were categorized into two groups: the younger group the majority of whom belonged to the age bracket 30 to 40 and the mature group whose ages ranged between 41 and 70 . The mean age of the farmers was 53.94 years old indicating that majority of the respondents were past middle age. This implies that there is going to be a replacement problem in the future if the sons and daughters of these farmers will not be encouraged to go farming.

On the average, the respondents had approximately 5.43 years of formal schooling implying that they only reached the intermediate level. Since education is related to the adoption of innovation wherein, the farmer with a higher level of education is more prone to adopt new farming technology. This result suggests that the adoption of technologies is slow and a problem in the study areas.

Almost all of the respondents were married. This suggests that young unmarried individuals are not engaged in farming. This is going to be a big problem of Eastern Samar if the youth would not be motivated to go to farming because older farmers generally lack the vigor to perform heavy farm jobs. 
Almost 9 out of 10 farmers were engaged in rice farming with coconut farming, vegetable raising, fishing, and carpentry work as their secondary farm work. It seems that the respondents were contented with rice farming as their main farm work.

Very few respondents had attended trainings related to rice farming. They claimed that they had no time, they were busy; and above all they were not informed of the schedule for the trainings. This is probably one of the reasons for the slow development of rice farming and cropping system in Samar.

The farmers' average in farming was 17.68 years suggesting that they had a lot of experience in rice farming using their own system of growing rice. With this number of years of experience it would be quite difficult for them to be convinced to change their old practices.

Rice farmers owned an average farm area of 1.26 hectares. This shows that each farmer has a wide land to be farmed. Consequently, development process of rice farming would rather be slow unless they would realize the value of improving their farm.

Most farmers were able to acquire their farm from their parents and grandparents although some of them had purchased their land. Given the proper education and practical training, these farmers would be able to be more productive considering that they own the land they till.

The study revealed that majority of the respondents were not members of any club or organization. They claimed that no benefits would be derived as members of the different organizations. Again education plays an important role for them to realize the value of organizations. These farmers should be motivated to appreciate the role and the benefits derived from becoming members of associations or organizations.

Table 1. Summary of farmers' characteristics in selected barangays in Can-avid and Dolores, Eastern Samar.

\begin{tabular}{|c|c|c|c|}
\hline \multicolumn{2}{|c|}{ Characteristics } & Number & Percent \\
\hline \multicolumn{4}{|l|}{ Age } \\
\hline $61-70$ & & 4 & 7.02 \\
\hline $51-60$ & & 14 & 24.56 \\
\hline $41-50$ & & 18 & 38.58 \\
\hline $31-40$ & & 14 & 24.56 \\
\hline \multirow[t]{3}{*}{ 30-below } & & $\underline{7}$ & 12.28 \\
\hline & Total & 57 & 100.00 \\
\hline & Mean 53.94 & & \\
\hline \multicolumn{4}{|l|}{ Educational Attainment } \\
\hline College (11-14) & & 3 & 5.26 \\
\hline High School (7-10) & & 15 & 26.32 \\
\hline Intermediate (5-6) & & 26 & 45.61 \\
\hline Primary Grades (1-4) & & 12 & 21.05 \\
\hline No Formal Schooling & & 1 & 1.76 \\
\hline & Total & 57 & 100.00 \\
\hline \multicolumn{4}{|l|}{ Civil Status } \\
\hline Married & & 56 & 98.25 \\
\hline \multirow[t]{2}{*}{ Single } & & 1 & 1.75 \\
\hline & Total & 57 & 100.00 \\
\hline \multicolumn{4}{|l|}{ Occupation } \\
\hline \multicolumn{4}{|l|}{ Main Farm Work } \\
\hline Rice Farming & & 56 & 89.47 \\
\hline \multirow[t]{2}{*}{ Coconut Farming } & & 1 & $\underline{10.53}$ \\
\hline & Total & $\overline{57}$ & $\overline{100.00}$ \\
\hline
\end{tabular}


Table 1. Continuation.

\begin{tabular}{|c|c|c|}
\hline \multirow{2}{*}{$\begin{array}{l}\text { Characteristics } \\
\text { Secondary Farm Work }\end{array}$} & Number & Percent \\
\hline & & \\
\hline Rice Farming & 5 & 8.77 \\
\hline Copra & 16 & 28.07 \\
\hline Vegetable Raising & 4 & 7.02 \\
\hline Fishing & 2 & 3.51 \\
\hline Barangay Captain & 1 & 1.75 \\
\hline Kagawad & 1 & 1.75 \\
\hline Carpenter & 2 & 3.51 \\
\hline Log Sower & 1 & 1.75 \\
\hline Tuba Gatherer & 2 & 3.51 \\
\hline Root Crop Production & 1 & 1.75 \\
\hline None & $\underline{22}$ & $\underline{38.60}$ \\
\hline Total & $\overline{57}$ & $\overline{100.00}$ \\
\hline \multicolumn{3}{|l|}{ Training Attended } \\
\hline \multicolumn{3}{|l|}{ Attended } \\
\hline Yes (attended) & 5 & 8.77 \\
\hline No (did not attend) & $\underline{52}$ & $\underline{91.23}$ \\
\hline Total & 57 & $\overline{100.00}$ \\
\hline \multicolumn{3}{|l|}{ Reasons for not attending } \\
\hline No time, busy working & 6 & 11.38 \\
\hline No invitation, busy working & 29 & 55.77 \\
\hline No organization & 3 & 5.77 \\
\hline Not interested & 1 & 1.92 \\
\hline No reason & $\underline{13}$ & 25.00 \\
\hline Total & 57 & 100.00 \\
\hline Types of Training & & \\
\hline About scientific farming & 3 & 5.26 \\
\hline About rice morphology & 1 & 1.75 \\
\hline About loan and scientific farming & 1 & 1.75 \\
\hline None & $\underline{52}$ & $\underline{91.23}$ \\
\hline Total & 57 & 99.84 \\
\hline Years in Farming & & \\
\hline $46-55$ & 2 & 3.51 \\
\hline $36-45$ & 4 & 7.02 \\
\hline $26-35$ & 5 & 8.77 \\
\hline $16-25$ & 17 & 29.82 \\
\hline $6-15$ & 18 & 31.58 \\
\hline 5 and below & 11 & 19.29 \\
\hline Total & 57 & 99.99 \\
\hline Mean & & 17.68 \\
\hline Land Owned & & \\
\hline Rice & 5 & 9.62 \\
\hline 2.10 and above & 25 & 48.07 \\
\hline $1.10-2.0$ & $\underline{22}$ & 42.31 \\
\hline $0.1-1.0$ & 52 & 100.00 \\
\hline Total & & \\
\hline Others (coco land) & 7 & 12.28 \\
\hline 2.10 and above & 3 & 5.26 \\
\hline $1.10-2.0$ & 23 & 40.35 \\
\hline $0.1-1.0$ & 24 & 42.11 \\
\hline
\end{tabular}


Table 1. Continuation.

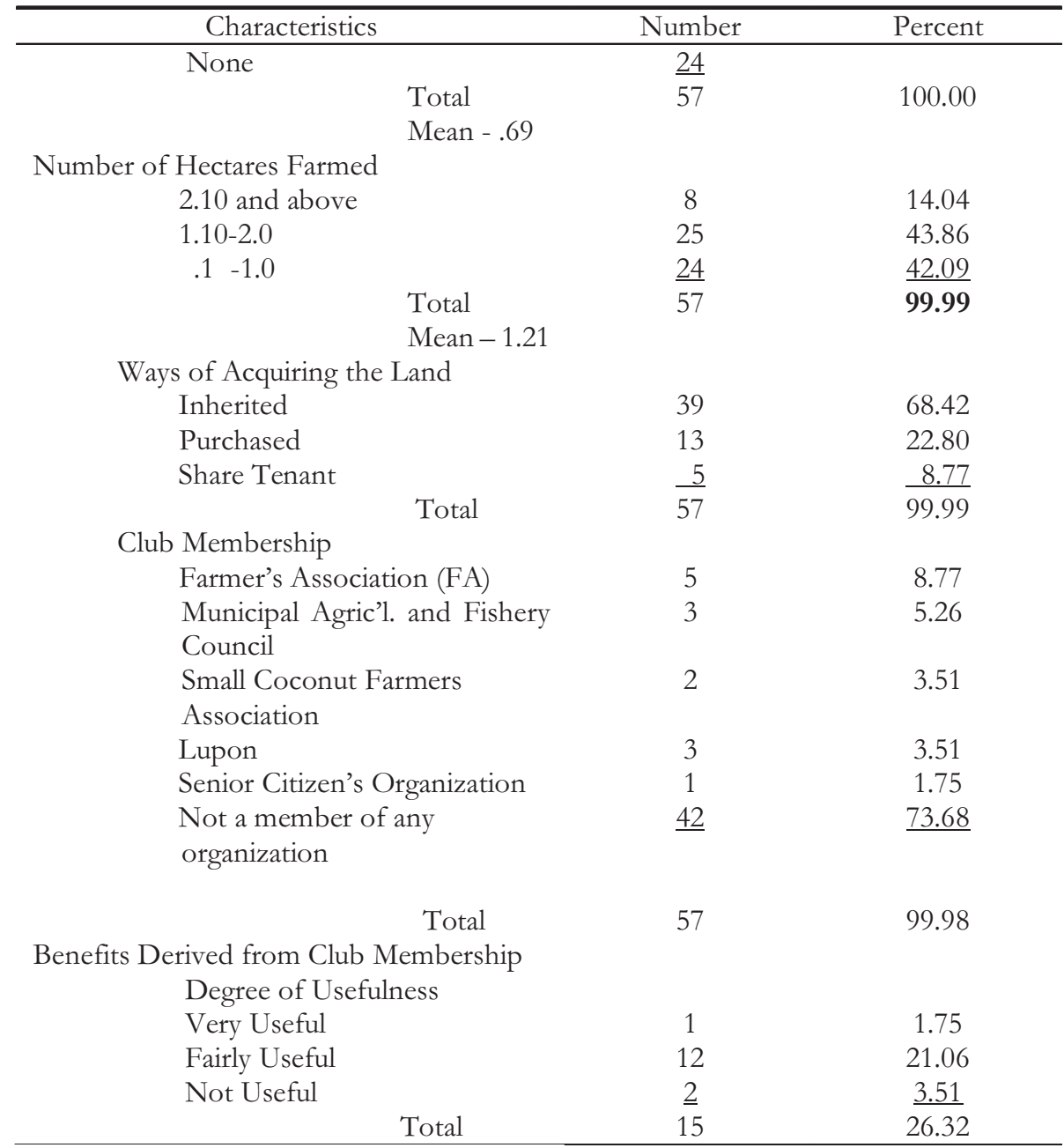

\section{Adoption on Indigenous Practices and Modern Technologies in Rice Farming}

\section{Modern Rice Technologies}

The rice farmers of Can-avid and Dolores, Eastern Samar had a minimal adoption of modern rice technologies. Most of the modern rice farming practices enumerated (Table 2) were only partially adopted by the respondents. It was only the "right planting time" which majority $(70.18 \%)$ of the respondents had adopted with a weighted mean score (WMS) of 1.81. This indicates that the acceptance by rice farmers of modern rice technologies has not yet been reached or achieved.

\section{Indigenous Rice Farming Technologies}

Generally, it was observed that the rice farmers of Can-avid and Dolores, Eastern Samar had practically practiced their own way of growing rice. They did not change their old practice of raising crops. They insisted on adopting their own indigenous practices of growing rice which they had practiced since they had started farming. In the project site, the use of winnowing basket in cleaning the palay is still practiced by majority of the farmers 
having a weighted mean score (WMS) of 2.23. They preferred to plant the traditional native seeds rather than the new high yielding IRRI varieties of rice. The practice of using native seeds by the farmers got a weighted mean score of (WMS) 2.5. Findings revealed that farmers prepared their rice fields by trampling with the use of carabao having a WMS of 2.04. This implies that the recent technique of land preparation had not been popularly used in these areas. Several reasons were raised why farmers who continuously used these technologies. In these regard, development efforts should therefore consider the sustainability of the technology suited to these areas.

Table 2. Degree of adoption by farmers of modern rice farming technologies in Can-Avid and Dolores, Eastern Samar.

\begin{tabular}{|c|c|c|c|c|c|c|c|}
\hline \multirow{3}{*}{$\begin{array}{c}\text { Recommended Modern Rice } \\
\text { Technologies }\end{array}$} & \multicolumn{6}{|c|}{ Degree of Adoption } & \multirow{3}{*}{ WMS* } \\
\hline & \multicolumn{2}{|c|}{$\begin{array}{l}\text { Did not } \\
\text { Adopt (1) }\end{array}$} & \multicolumn{2}{|c|}{$\begin{array}{c}\text { Partial } \\
\text { Adoption (2) }\end{array}$} & \multicolumn{2}{|c|}{$\begin{array}{c}\text { Full } \\
\text { Adoption (3) }\end{array}$} & \\
\hline & No. & $\%$ & No. & $\%$ & No. & $\%$ & \\
\hline $\begin{array}{l}\text { 1. Use of recommended seed } \\
\text { varieties (high yielding) }\end{array}$ & 41 & 71.93 & 12 & 21.05 & 4 & 7.02 & 1.25 \\
\hline $\begin{array}{l}\text { 2. Use of appropriate pest } \\
\text { control measure }\end{array}$ & 41 & 71.93 & 15 & 26.32 & 1 & 1.75 & 1.30 \\
\hline $\begin{array}{l}\text { 3. Use of soil fertility } \\
\text { improvement technique } \\
\text { (green manuring, application } \\
\text { of inorganic fertilizer) }\end{array}$ & 51 & 89.47 & 4 & 7.02 & 2 & 3.51 & 1.14 \\
\hline 4. Fertilizer application & 45 & 78.95 & 9 & 15.79 & 3 & 5.26 & 1.26 \\
\hline 5. Pesticide application & 42 & 73.68 & 14 & 24.56 & 1 & 1.75 & 1.24 \\
\hline 6. Good water management & 52 & 91.23 & 4 & 7.02 & 1 & 1.75 & 1.07 \\
\hline 7. Proper land preparation & 40 & 70.18 & 15 & 26.32 & 2 & 3.51 & 1.33 \\
\hline 8. Right seedbed preparation & 42 & 73.68 & 12 & 21.05 & 3 & 5.26 & 1.32 \\
\hline 9. Weeding & 49 & 85.95 & 6 & 10.53 & 2 & 5.26 & 1.18 \\
\hline 10. Treating seeds & 48 & 84.21 & 7 & 12.28 & 2 & 5.26 & 1.19 \\
\hline
\end{tabular}

*WMS- weighted mean score

Table 3. Degree of adoption by farmers of indigenous rice farming practices in Can-avid and Dolores, Eastern Samar

\begin{tabular}{|c|c|c|c|c|c|c|c|}
\hline \multirow{3}{*}{$\begin{array}{c}\text { Indigenous Rice Farming } \\
\text { Practices }\end{array}$} & \multicolumn{6}{|c|}{ Degree of Adoption } & \multirow{3}{*}{ WMS } \\
\hline & \multicolumn{2}{|c|}{$\begin{array}{l}\text { Did not } \\
\text { Adopt (1) }\end{array}$} & \multicolumn{2}{|c|}{$\begin{array}{c}\text { Partial } \\
\text { Adoption (2) }\end{array}$} & \multicolumn{2}{|c|}{$\begin{array}{l}\text { Full Adoption } \\
\text { (3) }\end{array}$} & \\
\hline & No. & $\%$ & No. & $\%$ & No. & $\%$ & \\
\hline 1. Trampling & 1 & 1.75 & 53 & 92.98 & 3 & 5.24 & 2.04 \\
\hline 2. Use of native seeds & - & - & 54 & 94.74 & 3 & 5.24 & 2.05 \\
\hline $\begin{array}{l}\text { 3. Direct seeding (broadcasting } \\
\text { method) }\end{array}$ & 43 & 75.44 & 10 & 17.54 & 4 & 7.02 & 1.32 \\
\hline $\begin{array}{l}\text { 4. Use of hot pepper juice mixed } \\
\text { with tide powder soap as } \\
\text { control of rice bug }\end{array}$ & 51 & 89.47 & 5 & 8.77 & 1 & 1.75 & 1.09 \\
\hline $\begin{array}{l}\text { 5. Use of sea weeds as control of } \\
\text { rice bug }\end{array}$ & 47 & 82.46 & 10 & 17.54 & 0 & 0 & 1.18 \\
\hline $\begin{array}{l}\text { 6. Diwata (pagtuna) before } \\
\text { harvesting }\end{array}$ & 9 & 15.79 & 48 & 84.21 & 0 & 0 & 1.84 \\
\hline $\begin{array}{l}\text { 7. Use of winnowing basket in } \\
\text { cleaning the palay }\end{array}$ & 2 & 3.51 & 40 & 70.18 & 15 & 26.31 & 2.23 \\
\hline 8. Use of "dalagdagan" threshing & 56 & 98.24 & 1 & 1.75 & 0 & 0 & 1.01 \\
\hline $\begin{array}{l}\text { 9. Use of mortar and pestle in } \\
\text { milling }\end{array}$ & 4 & 7.02 & 51 & 89.47 & 2 & 3.51 & 1.96 \\
\hline
\end{tabular}




\section{Performance of Indigenous Rice Farmers}

The study revealed that the rice farmers interviewed had poor performance based on the result of the BRANDAT of whom $71.05 \%$ were poorly motivated/unsuccessful, suggesting that farmers have low in rice farm income for rice, low in income outside the farm and also low community involvement. It also suggests that their production was low and that they had less interest in farming. Unless something would be done to motivate them to work hard, they cannot increase the yield of their rice farms. Only $28.93 \%$ had very good performance, successful or highly motivated group as reflected in Figure 2.

\section{Performance of Modern Rice Farmers}

Based on the results of BRANDAT farmers using modern farm practices had very poor performance; of which 66.75 percent of whom were poorly motivated or unsuccessful and were further characterized as low in rice farm income as well as in income outside the farm and in community involvement. Only 33.25 percent were successful or highly motivated group. If these farmers would employ the modern and approved practices in growing rice, there is still a need to motivate and encourage them to improve their system of farming as reflected in Figure 3.

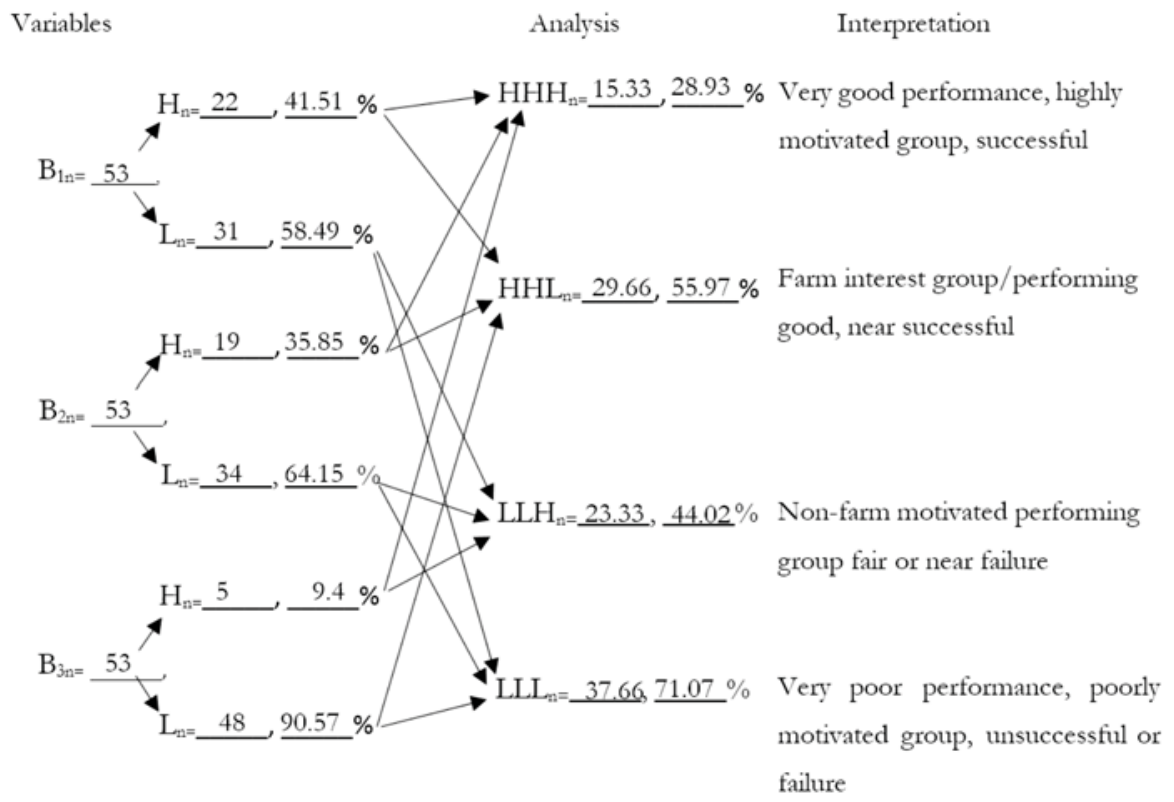

Code:

$\mathrm{H}-$ Average and above average

L-Below Average

Benefits:
$\mathrm{B}_{1}$ - Income in rice farming
$\mathrm{B}_{2}$-Off-farm income
$\mathrm{B}_{3}$-Social and involvement in community related services

Figure 2. Performance of Rice Farmers Adopting the Indigenous Rice Farming Practices. 


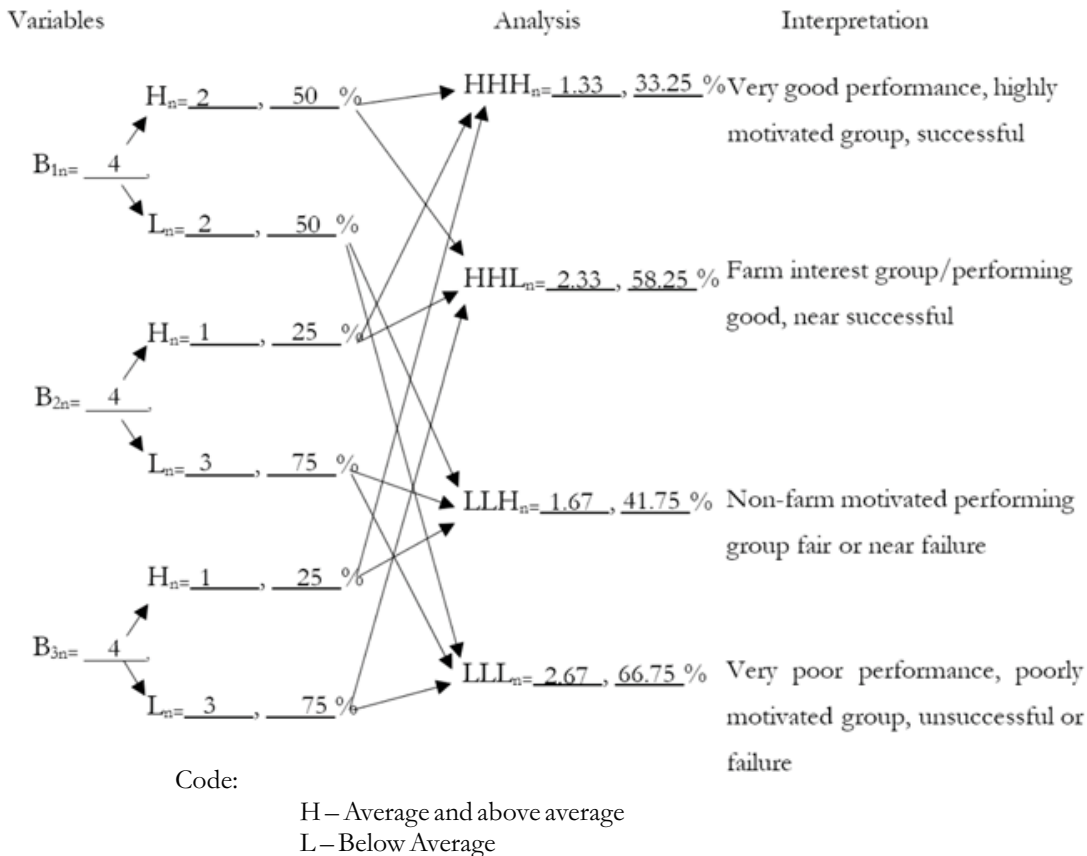

Benefits:

$\mathrm{B}_{1}-$ Income in rice farming
$\mathrm{B}_{2}-$ Off-farm income
$\mathrm{B}_{3}-$ Social and involvement in community related services

Figure 3. Performance of Rice Farmers Adopting the Modern Technologies

\section{Performance of Rice Farmers Adopting both Modern and Indigenous Practices}

Of the farmers who were using indigenous and some of the recommended practices in raising rice, 70.18 percent were unsuccessful and considered very poor in performance or poorly motivated based on the result of BRANDAT. They were characterized as low in rice farm income, in income outside the farm, and in community involvement. Only 28.82 percent were considered successful or highly motivated group. This implies that even if the farmers would use either technology in raising rice, but they are not well motivated to work in the farm, it would result in poor performance (Figure 4).

Problems of Rice Farmers in Adopting the Modern and Indigenous Practices

\section{Modern Rice Technologies}

Many problems had been raised by the respondents on using the recommended modern rice practices. Of the different recommended practices (Table 3), the problem on inadequacy of water to irrigate the rice field ranked first followed by the problem on (intensive care) weeding. Although these problems were related to each other, the latter problem could be solved if they had the capital. This implies that the farmers have not yet been educated and are not well informed on several funding agencies or organizations that could be tapped as sources of funding. Minor problems such as expensive and no recommended seeds, chemicals (pesticide and insecticide) available in the locality which ranked second and third, respectively, could still be enhanced if they had money to support their farming activities. 


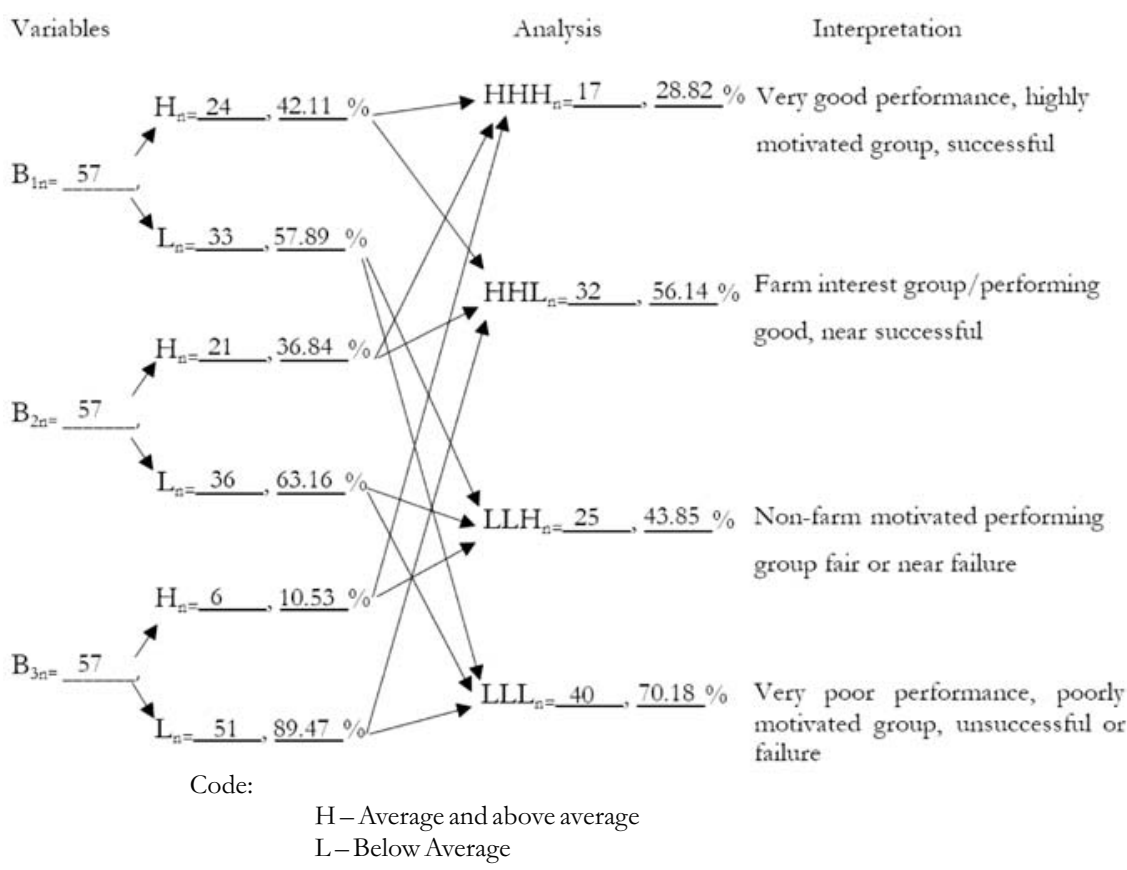

Benefits:

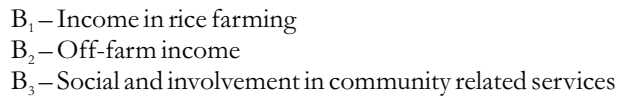

Figure 4. Performance of Rice Farmers Adopting both Modern and the Indigenous Rice Practices.

\section{Indigenous Rice Technologies}

The traditional farmers had several problems on their own way of rice farming. But this did not bother them much compared to those farmers who had used some of the recommended modern rice practices. On trampling their rice field, the problem that ranked first was the need for two or more carabaos. On problems related to direct seeding, fast growing of weeds ranked first. The farmers were already contented on trampling the land during preparation; they were also contented using native seeds (own seeds). Although they had no cash, they could still produce rice. Moreover, the farmers preferred the native rice varieties because they grow taller than the weeds, unlike the modern rice varieties which are short that need intensive weeding. This implies that the technology to be introduced should be modified in such a way that it would be economically feasible and sustainable in the area.

Table 3. Problems of farmers in adopting the modern and indigenous rice technologies.

\begin{tabular}{llcc}
\hline $\begin{array}{c}\text { Recommended Modern } \\
\text { Rice Practices }\end{array}$ & \multicolumn{1}{c}{ Problems } & $\begin{array}{c}\text { Number of } \\
\text { Respondents* } \\
\text { (N-57) }\end{array}$ & Rank \\
\hline $\begin{array}{l}\text { 1. Use of } \\
\text { recommended seeds } \\
\text { varieties }\end{array}$ & $\begin{array}{l}\text { Needs ample water (controlled) } \\
\text { Needs intensive care weeding } \\
\text { etc. } \\
\text { Expensive and no } \\
\text { recommended seed available } \\
\text { No knowledge/skill }\end{array}$ & 30 & 1 \\
& & 24 & 3 \\
\hline
\end{tabular}


Table 3. Continuation.

\begin{tabular}{|c|c|c|c|}
\hline $\begin{array}{l}\text { Recommended Modern } \\
\text { Rice Practices }\end{array}$ & Problems & $\begin{array}{c}\text { Number of } \\
\text { Respondents* } \\
\text { (N-57) }\end{array}$ & Rank \\
\hline \multirow{4}{*}{$\begin{array}{l}\text { 2. Use of soil fertilizer } \\
\text { improvement } \\
\text { technique } \\
\text { manuring) }\end{array}$} & $\begin{array}{l}\text { No farm implements (plow, } \\
\text { sprayer etc.) }\end{array}$ & 40 & 1 \\
\hline & No knowledge/skill & 32 & 2 \\
\hline & Need capital & 13 & 3 \\
\hline & Laborious & 9 & 4 \\
\hline \multirow{4}{*}{$\begin{array}{l}\text { 3. Use appropriate pest } \\
\text { control measure }\end{array}$} & No knowledge/skill & 28 & 1.5 \\
\hline & $\begin{array}{l}\text { No chemicals available in the } \\
\text { locality }\end{array}$ & 28 & 1.5 \\
\hline & No money & 12 & 3 \\
\hline & $\begin{array}{l}\text { No farm implements (plow, } \\
\text { sprayer etc.) }\end{array}$ & 9 & 4 \\
\hline \multirow[t]{4}{*}{ 4. Fertilizer application } & No irrigation water & 50 & 1 \\
\hline & Needs capital & 34 & 2 \\
\hline & $\begin{array}{l}\text { No fertilizer available in the } \\
\text { locality }\end{array}$ & 26 & 3 \\
\hline & No knowledge and skill & 13 & 4 \\
\hline \multirow[t]{2}{*}{ 5. Pesticide application } & No sprayer & 42 & 1 \\
\hline & Needs capital (expensive) & 24 & 2 \\
\hline \multirow{5}{*}{$\begin{array}{l}\text { 6. Good water } \\
\text { management }\end{array}$} & No irrigation water & 54 & 1 \\
\hline & No response & 15 & 2 \\
\hline & No farm implements & 7 & 3 \\
\hline & Needs capital & 2 & 4 \\
\hline & No knowledge and skill & 1 & 5 \\
\hline \multirow[t]{5}{*}{$\begin{array}{l}\text { 7. Proper } \\
\text { preparation }\end{array}$} & $\begin{array}{l}\text { No farm implements } \\
\quad \text { (plow etc.) }\end{array}$ & 50 & 1 \\
\hline & Needs capital & 10 & 2 \\
\hline & No knowledge/skill & 9 & 3 \\
\hline & Laborious & 8 & 4 \\
\hline & Needs more workers & 5 & 5 \\
\hline \multirow{7}{*}{$\begin{array}{l}\text { 8. Right seedbed } \\
\text { preparation }\end{array}$} & Laborious & 16 & 1 \\
\hline & No farm implements & 14 & 2 \\
\hline & No knowledge/skill & 13 & 3 \\
\hline & Needs capital & 8 & 4 \\
\hline & Needs more workers & 6 & 6 \\
\hline & Time consuming & 3 & 6.5 \\
\hline & $\begin{array}{l}\text { Needs sufficient water } \\
\text { (controlled) }\end{array}$ & 3 & 6.5 \\
\hline \multirow[t]{5}{*}{ 9. Weeding } & Needs capital & 33 & 1 \\
\hline & Laborious & 27 & 2 \\
\hline & Needs more workers & 13 & 3 \\
\hline & No knowledge/skill & 3 & 4 \\
\hline & Time consuming & 1 & 5 \\
\hline \multirow[t]{4}{*}{ 10. Treating seeds } & No knowledge/skill & 51 & 1 \\
\hline & No chemicals available & 48 & 2 \\
\hline & Needs capital & 24 & 3 \\
\hline & No equipment & 7 & 4 \\
\hline
\end{tabular}


Table 3. Continuation.

\begin{tabular}{|c|c|c|c|}
\hline $\begin{array}{l}\text { Indigenous Rice } \\
\text { Practices }\end{array}$ & Problems & $\begin{array}{c}\text { Number of } \\
\text { Respondents* } \\
(\mathrm{N}-57)\end{array}$ & Rank \\
\hline \multirow[t]{6}{*}{ 1. Trampling } & $\begin{array}{l}\text { Needs at least two or more } \\
\text { carabaos }\end{array}$ & 60 & 1 \\
\hline & $\begin{array}{l}\text { Difficult to loosen especially if } \\
\text { there is no water available }\end{array}$ & 9 & 2 \\
\hline & Time consuming & 5 & 3 \\
\hline & Not properly prepared & 4 & 4 \\
\hline & No problem & 3 & 5 \\
\hline & Laborious & 2 & 6 \\
\hline \multirow[t]{4}{*}{ 2. Use of native seeds } & No problem & 48 & 1 \\
\hline & Sometimes low harvest & 26 & 2 \\
\hline & Tall & 5 & 3 \\
\hline & Late maturing & 2 & 4 \\
\hline \multirow{3}{*}{$\begin{array}{l}\text { 3. Direct seeding } \\
\text { (broadcasting) }\end{array}$} & Weeds easily grow & 60 & 1 \\
\hline & Do not use & 17 & 2 \\
\hline & $\begin{array}{l}\text { Sometimes eaten by birds and } \\
\text { rats }\end{array}$ & 10 & 3 \\
\hline \multirow{3}{*}{$\begin{array}{l}\text { 4. Use of hot pepper } \\
\text { juice mixed with tide } \\
\text { (powder soap) as } \\
\text { control for rice bug }\end{array}$} & Do not use & 51 & 1 \\
\hline & $\begin{array}{l}\text { Sometimes not effective } \\
\text { especially during rainy days }\end{array}$ & 39 & 2 \\
\hline & $\begin{array}{l}\text { Run out of materials } \\
\text { (hot pepper fruit) }\end{array}$ & 3 & 3 \\
\hline \multirow{3}{*}{$\begin{array}{l}\text { 5. Use of sea weeds as } \\
\text { control of rice bug }\end{array}$} & Do not use & 50 & 1 \\
\hline & Laborious/bulky & 48 & 2 \\
\hline & Sometimes not available & 2 & 3 \\
\hline \multirow{3}{*}{$\begin{array}{r}\text { 6. Diwata (pagtuna) } \\
\text { while harvesting }\end{array}$} & No problem & 40 & 1 \\
\hline & $\begin{array}{l}\text { Sometimes causes delay in } \\
\text { working }\end{array}$ & 20 & 2 \\
\hline & Sometimes not effective & 6 & 3 \\
\hline \multirow{2}{*}{$\begin{array}{l}\text { 7. Use of "dalagdagan" } \\
\text { while threshing }\end{array}$} & Do not use & 53 & 1 \\
\hline & $\begin{array}{l}\text { Only one can use at a } \\
\text { time/limited space }\end{array}$ & 49 & 2 \\
\hline \multirow{3}{*}{$\begin{array}{l}\text { 8. The use of mortar } \\
\text { and pestle in the } \\
\text { absence of rice mill. }\end{array}$} & Difficult job & 69 & 1 \\
\hline & Time consuming & 56 & 2 \\
\hline & No problem & 40 & 3 \\
\hline \multirow{3}{*}{$\begin{array}{l}\text { 9. The use of } \\
\text { winnowing basket in } \\
\text { cleaning the palay. }\end{array}$} & No response & 49 & 1 \\
\hline & Time consuming & 45 & 2 \\
\hline & Difficult when not windy & 38 & 3 \\
\hline
\end{tabular}

*Multiple response 


\section{CONCLUSIONS}

Based on the findings of the study, the following conclusions were drawn:

1. The respondents continuously practiced the old way of raising rice because they could hardly afford to buy or rent farm equipment and facilities for modern rice farming. They also lacked knowledge and skills on the recommended modern rice practices.

2. The local rice farmers manifested creativity for tilling their own rice farms. Some of them practiced the traditional or old method of rice farming, while others applied both the modern and the indigenous rice technologies.

\section{RECOMMENDATIONS}

Based on the findings of the study, the following recommendations can be drawn:

1. Incentives from lending institutions should be made available to local farmers, like cash loans for production capital or the availability of equipment for agricultural production. These loans should be extended to the farmers with affordable modes of payment. With this assistance, the farmers would be motivated to adopt the recent farming technologies. Similarly, efforts should be made in such a way that these technologies be economically feasible, socially acceptable, and sustainable in the area.

2. Introduction of rice technologies and the implementation of rural development programs should be locale-specific or area-based particularly on harnessing the local materials or indigenous resources of the farmers to be employed for the improvement of rice farming operations.

3. The extension workers in the area should therefore initiate and conduct trainings for the local farmers. The training should focus on technologies suitable to the place. This further suggests that the development workers and change agents should look into the existing resources of the farmers and their capabilities and from there, an enriched rice farming technology introduction should evolve.

4. A model barangay family farm may be established in the area where farmers are practicing indigenous farming. It must showcase the farm inputs and other farm implements to be used for the improvement of their farms.

\section{REFERENCES}

ASINOV, J. E. 2013. Agricultural Production. Random Exports, Mehra Printers, New Delhi, India.

FERGLIE, F.O. 2012. Productivity Growth in Agriculture. An International Perspective. UK, CPI Group (UK) Ltd.

HARRIS, B.M. 1979. Orientation in Branching Diagram Analysis. Studies in Educational Evaluation 5: 157-161.

IRRI, 2014. Annual Report. International Rice Research Institute, DAPO Box 777, Metro Manila.

KRANZBERG, F. S. 1977. Technology, Mc Graw Hill Encyclopedia of Science and Technology. Vol. 3. New York; Mc Graw Hill Book Company.

PHILRICE, 2014. Philrice Magazine. A quarterly publication of the Philippine Rice Research Institute. 27(4).

RICKETTS, C. and RICKETTS K. 2013. Agribusiness Fundamentals and Application. 2nd Ed. Cengage Learning Asia Pte. Ltd., MG Reprographics Phils.

STRASBOURG, L. K. 2013. Agricultural Business Management. Random Exports, New Delhi, India 